\title{
HUBUNGAN KEYAKINAN DIRI MENGELOLA KONFLIK KERJA-KELUARGA, DUKUNGAN ATASAN, DUKUNGAN KELUARGA DENGAN PENGAYAAN KERJA- KELUARGA
}

\author{
Artiawati \& Neni Puji Astutik \\ Fakultas Psikologi, Universitas Surabaya \\ artiawati@staff.ubaya.ac.id
}

\begin{abstract}
ABSTRAK
Perkembangan jaman mengakibatkan banyak terjadi pergeseran dalam bidang kehidupan, salah satunya adalah terjadinya pergeseran peran dalam rumah tangga, seperti semakin banyaknya pasangan dual karir. Dual karir tentunya akan menimbulkan tantangan tersendiri dalam pengelolaan domain kerja dan rumah tangga. Penelitian ini bertujuan untuk menguji hubungan keyakinan diri mengelola konflik kerja-keluarga, dukungan atasan dan dukungan keluarga besar dengan pengayaan kerja-keluarga. Partisipan penelitian ini sebanyak 250 guru di Surabaya. Penelitian ini menggunakan pendekatan kuantitatif dan pengumpulan data melalui kuisioner. Alat ukur yang digunakan dalam penelitian ini, yaitu kuesioner pengayaan kerja-keluarga dibuat oleh Carlson, Kacmar, Waybe \& Grzywacz (2006) dan keyakinan diri mengelola konflik kerja-keluarga dibuat oleh Cinamon (2003) yang diadaptasi oleh Artiawati dan Andhini (2016). Kuesioner dukungan atasan dan dukungan keluarga besar yang dibuat oleh Antani dan Ayman (2003) dengan tim project 3535 dan didaptasi oleh Artiawati (2012). Data yang diperoleh diolah menggunakan SPSS dengan teknik analisis regresi ganda. Hasil yang didapatkan,antara lain:(1)ada hubungan yang signifikan antara keyakinan diri mengelola konflik kerja-keluarga, dukungan atasan, dan dukungan keluarga besar dengan pengayaan kerjakeluarga $(F=25.032 ; p<0.05 ; R$ square $=0.234)$. (2) keyakinan diri mengelola konflik kerja-keluarga memiliki hubungan paling kuat dengan pengayaan kerja-keluarga ( $r$ parsial 0.259 ; $p<0,05$ ). Saran untuk penelitian selanjutnya perlu melibatkan variabel lain seperti kepribadian, konflik kerja-keluarga, juga mempertimbangkan latar belakang kultural.
\end{abstract}

Kata kunci: keyakinan diri mengelola konflik kerja-keluarga, dukungan keluarga besar, dukungan atasan, guru.

\begin{abstract}
Current development caused many shifts occurs, which one is the occurance of role shift in the household, such as increasing number of dual career couples. Dual career will certainly pose its own challenges to manage work-family domains. This study aims to examine correlation between WFCSE, supervisor support, extended family support with WFE. Participants of this study were 250 teachers in Surabaya. This research uses quantitative approach and data collection through questionnaire. Measurement instrument that used in this study were WFE questionnaire created by Carlson, Kacmar, Waybe \& Grzywacz (2006), WFCSE created by Cinamon (2003) adapted by Artiawati and Andhini (2016). Supervisor support and family support questionnaires were created by Antani and Ayman (2003) with project team 3535 adapted by Artiawati (2012). The data obtained were processed using SPSS with multiple regression analysis technique. Results obtained were:(1) there is a significant correlation between WFCSE, supervisor support and extended family support with WFE ( $F=25$ 032; $P<0.05$; $R$ square =0234). (2) WFCSE has the strongest correlation with WFE (partial $r$ 0.259; $p$ <0.05). Suggestions for further research need to involve other variables such as personality, WFC. as well as the need to study WFE when viewed from the cultural background.
\end{abstract}

Keyword : WFCSE, supervisor support, extended family support, work-family enrichment, teacher 


\section{Journal of Psychological Science and Profesion (JPSP)}

Vol.1, No.1, Desember 2017

E-mail: jpsp@unpad.ac.id

\section{PENDAHULUAN}

Perkembangan jaman yang semakin pesat menuntut setiap orang untuk mampu menyesuaikan diri dengan kondisi yang ada. Situasi tersebut menjadikan banyak pasangan yang memutuskan untuk bersama-sama menjalani pekerjaan di luar rumah, sehingga membuat peranan perempuan meningkat dengan mengambil peran untuk bekerja disamping menjalankan perannya sebagai seorang ibu rumah tangga. Perubahan juga terlihat pada tingkat pendidikan, di mana perempuan memasuki dan lulus dari pendidikan pada tingkat yang sama atau lebih tinggi daripada laki-laki. Pekerjaan dan keluarga merupakan dua domain dimana manusia dewasa menghabiskan sebagian besar waktunya. Walaupun berbeda, pekerjaan dan keluarga interdependen satu sama lain sebagaimana keduanya berkaitan dengan pemenuhan hidup seseorang. Pembagian peran pekerjaan dan tugas keluarga di masa lalu sangatlah jelas, suami berperan sebagai pencari nafkah melalui pekerjaannya, sedangkan istri berperan merawat keluarga dan anak-anak. Sejalan dengan perkembangan bisnis dan dunia usaha, kesempatan menempuh pendidikan dan bekerja tidak hanya terbuka bagi lelaki namun juga perempuan. Peningkatan jumlah pasangan suami dan istri yang bekerja dengan anak yang masih kecil dan perubahan struktur keluarga yang dulunya tradisional telah menghasilkan perubahan di dalam rumah serta pembagian tanggung jawab keluarga bagi laki-laki dan perempuan.

Organisasi Buruh Internasional (ILO) mencatat pertumbuhan jumlah pekerja perempuan meningkat setiap tahunnya. Pada 2015, sebanyak $38 \%$ dari 120 juta pekerja di Indonesia adalah perempuan. Berdasarkan proporsi pekerja menurut bidang pekerjaannya, perempuan paling dominan bekerja di bidang pekerjaan profesional dan jasa serta bagian penjualan, di mana proporsi perempuan adalah sebesar 57,2 \% dan 53,9 \% pada Agustus 2014. Sedangkan laki-laki paling dominan bekerja sebagai operator di pabrik, operator mesin dan tenaga perakit sebanyak $87,1 \%$ dan sebagai legislator, pegawai senior dan manajer sebanyak $77,3 \%$ (ILO, 2015). Menyeimbangkan peran dalam pekerjaan dan keluarga tentu saja dapat meningkatkan konflik interpersonal dan intrapersonal pada perempuan dan laki-laki yang secara bersamaan mempertahankan tanggung jawab profesional dan tanggung jawab pribadi.

Ewing dan Smith (2003) melaporkan bahwa antara $25 \%$ sampai dengan $40 \%$ guru di negaranegara barat meninggalkan pekerjaan mereka atau menghadapi sindrom burnout. Saat ini, tugas guru beragam karena mereka melakukan tidak hanya mengajar tetapi juga hal penting terkait dengan kurikulum, siswa, orang tua, dan komunitas sekolah, ugas tersebut membuat waktu yang dihabiskan untuk menyelesaikan pekerjaan akan lebih banyak dibandingkan dengan sebelumnya sehingga kondisi tersebut juga bisa memicu terjadinya konflik peran dalam domain pekerjaan dan keluarga.

Konflik yang terjadi karena adanya peran pada domain kerja-keluarga, tidak sepenuhnya menimbulkan interaksi negatif antara domain kerja-keluarga, tapi kedua domain tersebut dapat berinteraksi secara positif (Greenhaus, Jeffrey, \& Romila, 2007; Gareis, Barnett, Ertel, \& Berkman, 2009). Interaksi positif antara domain kerjakeluarga dapat terjadinya karena adanya kemampuan dalam menghadapi konflik yang terjadi dalam dua domain tersebut. Kemampuan dalam menghadapi konflik tersebut berhubungan dengan adanya keyakinan seseorang akan kemampuan dirinya dalam menyelesaikan konflik yang terjadi, hal tersebut adalah keyakinan diri mengelola konflik kerja-keluarga (work famiy conflict self efficacy). Semakin banyak pengalaman berhasil individu dalam mengelola konflik peran dalam domain kerja dan keluarga, maka akan semakin tinggi tingkat keyakinan diri mengelola konflik kerja-keluarga orang tersebut. Keyakinan diri mengelola konflik kerja-keluarga pada diri individu akan membantu orang tersebut mengelola interaksi peran domain kerja-keluarga menjadi interaksi positif, dan selanjutnya interaksi positif tersebut menimbulkan pengayaan kerja-keluarga (work- family enrichment). Pengayaan kerja-keluarga terjadi ketika peran yang dilakukan dalam pekerjaan dan peran yang dilakukan dalam keluarga saling memberikan konstribusi positif dan keuntungan (Bhargava \& Baral, 2009). Menurut Hennessy (2007), terdapat tiga faktor yang memengaruhi pengayaan kerja-keluarga, yaitu: (1) konflik kerja-keluarga adalah konflik interperan dimana seseorang yang terlibat dalam satu peran misalnya pekerjaan, bertentangan dengan keterlibatan seseorang pada peran lainnya misalnya keluarga; (2) keyakinan diri mengelola konflik kerja-keluarga didefinisikan sebagai 


\section{Journal of Psychological Science and Profesion (JPSP)}

Vol.1, No.1, Desember 2017

E-mail: jpsp@unpad.ac.id

keyakinan individu dalam dirinya atau kemampuan untuk mengelola konflik kerjakeluarga dan konflik keluarga-kerja; (3) dukungan sosial, dukungan sosial didefinisikan sebagai sumber yang dapat mengurangi efek negatif dari sumber stres dan dapat meningkatkan kesehatan dan juga kesejahteraan.

Dukungan sosial yang berasal baik dari domain keluarga maupun domain kerja mampu untuk memperluas sumber daya individu melalui keterampilan akuisisi dan pengaruh positif yang memfasilitasi proses pengayaan kerja-keluarga (Greenhaus \& Powell, 2006; Schein \& Chen, 2011). Pada masyarakat Indonesia yang memiliki kolektivisme tinggi dan berorientasi pada keluarga, peran dukungan sosial yang berasal dari keluarga dapat menurunkan tingkat konflik kerja-keluarga, sehingga memudahkan para pekerja dalam menjalani kehidupan kerja dan keluarganya secara seimbang (Artiawati, 2017). Kondisi tersebut memungkinkan individu mengalami peningkatan kinerja dalam peran mereka sebagai orang tua serta pekerja. Individu dapat menerima dukungan sosial dengan cara yang berbeda dan dari sumber yang berbeda. Di tempat kerja, tiga sumber dukungan sosial yang paling menonjol bagi karyawan adalah supervisor, top management dan rekan kerja. Ketiga sumber dukungan berbasis kerja menawarkan dukungan dalam berbagai cara, seperti memberikan pemahaman empatik atau memungkinkan individu mengatur waktu libur untuk menyelesaikan tugas terkait keluarga (Kossek, Pichler, Bodner, \& Hammer, 2011). Sama halnya seperti berbagai sumber dukungan dari domain kerja, domain keluarga juga menawarkan beberapa bentuk dukungan sosial yang bisa meningkatkan pengayaan kerjakeluarga. Dukungan pasangan dan keluarga besar dianggap sebagai bentuk dukungan yang paling berharga dari domain keluarga.

Terdapat beberapa penelitian yang telah mengkaji pengayaan kerja-keluarga antara lain Penelitian Hennesy (2007) menjelaskan bahwa dari sisi positif (work/family enrichment) dan negatif (work/family conflict) keduanya dapat menyeimbangkan peran ganda termasuk dalam model konseptual. Hasil penelitian Wallace (2014) menunjukkan bahwa dukungan rekan kerja dan dukungan suami-istri adalah prediktor signifikan secara statistik dari WFE.

Hal tersebut membuat peneliti tertarik untuk meneliti hubungan antara keyakinan diri mengelola konflik kerja-keluarga, dukungan atasan (domain kerja), dan dukungan keluarga besar (domain keluarga) dengan pengayaan kerja-keluarga.

\section{METODE}

Responden penelitian ini sebanyak 250 guru SMPN dan SMAN di wilayah surabaya yang memenuhi karakteristik penelitian. Teknik pengambilan sampel yang digunakan dalam penelitian ini adalah dengan cara accidental sampling. Metode pengumpulan data yang digunakan dalam penelitian ini adalah wawancara untuk mendapatkan data survei awal, metode kuantitatif menggunakan angket (kuesioner). Dalam penelitian ini, instrumen yang digunakan sadalah angket terbuka dan kuisioner dengan jenis self report scale yang menggunakan bentuk skala Likert.

Instrumen dalam penelitian ini adalah angket pengayaan kerja-keluarga yang tersusun atas 18 aitem yang dibuat oleh Carlson, Kacmar, Waybe \& Grzywacz (2006) yang diadaptasi oleh Artiawati dan Andhini (dalam Andhini 2016). Variabel keyakinan diri mengelola konflik kerjakeluarga diukur dengan angket keyakinan diri mengelola konflik kerja-keluarga yang tersusun atas 10 aitem yang dibuat oleh Cinamon (2003) yang diadaptasi oleh Artiawati dan Andhini (dalam Andhini 2016). Dukungan atasan diukur menggunakan angket dukungan atasan yang dibuat oleh tim project 3535, angket ini selanjutnya diadaptasi oleh Artiawati (2012). Dukungan keluarga besar diukur menggunakan angket dukungan keluarga besar tersusun atas 5 aitem yang dibuat tim project 3535, angket ini selanjutnya diadaptasi oleh Artiawati (2012).

Pengolahan data dilakukan dengan menggunakan program SPSS untuk memperoleh nilai reliabilitas, uji linieritas dan uji hipotesis. Metode analisis yang digunakan dalam penelitian ini adalah analisis regresi ganda karena dalam penelitian terdapat lebih dari satu independent variabel (IV). Hasil uji regresi digunakan untuk uji hipotesis mayor dan hasil uji korelasi parsial digunakan untuk uji hipotesis minor.

\section{HASIL DAN PEMBAHASAN}

Responden penelitian ini sebanyak 250 orang yang terdiri atas 169 orang (67.6\%) perempuan dan 81 orang (32.4\%) laki-laki. Mayoritas usia partisipan berusia sekitar 51-55 tahun sebanyak 


\section{Journal of Psychological Science and Profesion (JPSP)}

Vol.1, No.1, Desember 2017

E-mail: jpsp@unpad.ac.id

59 orang (23.6 \%) dan usia 46-50 tahun sebanyak (25.6\%). Mayoritas partisipan bekerja selama 16-20 tahun, yaitu sebanyak 69 orang (27.6\%). Partisipan dalam penelitian ini adalah guru PNS, sehingga mayoritas mereka bekerja sudah cukup lama dan usia mereka juga sudah memasuki usia dewasa madya.

Pengujian reliabilitas untuk alat ukur pengayaan kerja-keluarga (work family enrichment), keyakinan diri mengelola konflik kerja-keluarga (work family conflict self efficacy), dukungan atasan dan dukungan keluarga besar yang dipakai menunjukkan hasil yang reliabel, dengan nilai alpha cronbach sebagai berikut :

Tabel.1 Hasil Uji Reliabilitas

\begin{tabular}{llcl}
\hline $\mathbf{N}$ & Alat Ukur & $\begin{array}{c}\text { Alpha } \\
\text { Cronbach }\end{array}$ & Status \\
\hline 1 & $\begin{array}{l}\text { Pengayaan Kerja- } \\
\text { Keluarga (WFE) }\end{array}$ & 0.902 & Reliabel \\
2 & $\begin{array}{l}\text { Keyakinan Diri } \\
\text { Mengelola Konflik }\end{array}$ & 0.775 & Reliabel \\
& $\begin{array}{l}\text { Kerja-Keluarga } \\
\text { (WFCSE) }\end{array}$ & \\
& $\begin{array}{l}\text { Dukungan Atasan } \\
\text { Dukungan Keluarga }\end{array}$ & 0.786 & Reliabel \\
4 & Besar & Reliabel \\
\hline
\end{tabular}

Alat ukur tersebut digunakan untuk mengambil data dari sebanyak 250 orang responden, dan hasil data yang diperoleh dianalisis dengan menggunakan uji regresi. Berikut ini adalah hasil hipotesis mayor dilakukan dengan analisis regresi ganda sebagai berikut:

Tabel 2. Uji Hipotesis Mayor

\begin{tabular}{lllll}
\hline Variabel & $\mathbf{R}$ & $\mathbf{R}^{2}$ & $\mathbf{F}$ & $\mathbf{P}$ \\
\hline Keyakinan Diri & & & & \\
Mengelola & & & \\
Konflik Kerja- & & & \\
Keluarga, & & & \\
Dukungan & & & \\
Atasan, & 0.484 & 0.234 & 25.03 & 0.001 \\
Dukungan & & & & \\
Keluarga Besar & & & & \\
dengan & & & & \\
Pengayaan & & & & \\
Kerja-Keluarga & & & & \\
\hline
\end{tabular}

Hasil uji hipotesis mayor menunjukkan bahwa nilai $F$ sebesar 25.032 dan nilai $p$ kurang dari 0,05 yang berarti bahwa ada hubungan yang signifikan antara keyakinan diri dalam mengelola konflik kerja-keluarga, dukungan atasan dan dukungan keluarga besar dengan pengayaan kerja-keluarga. Hubungan yang signifikan tersebut menunjukkan bahwa partisipan yang memiliki keyakinan diri tinggi dalam mengelola konflik kerja-keluarga dan mendapatkan dukungan atasan serta mendapatkan dukungan dari keluarga besar akan memiliki pengayaan kerja keluarga yang baik. Nilai $\mathrm{R}$ square didapat 0.234 yang berarti bahwa artinya keyakinan diri dalam mengelola konflik kerja-keluarga, dukungan atasan, dan dukungan keluarga besar memiliki sumbangan efektif sebesar $23.4 \%$ dalam menjelaskan pengayaan kerja-keluarga. Hasil temuan ini mendukung penelitian Hennessy (2007) bahwa dukungan sosial (domain kerja dan keluarga) dan keyakinan diri mengelola konflik kerja-keluarga memiliki hubungan yang positif dengan pengayaan kerja-keluarga, serta pengayaan kerja-keluarga merupakan mediator yang dapat memengaruhi work satisfaction dan family satisfaction. Penelitian dengan topik ini masih sangat jarang diteliti, sehingga literatur penelitian yang tersedia juga terbatas.

Greenhaus dan Parasuraman (1999) mengatakan bahwa keterlibatan dalam satu peran tertentu memungkinkan individu untuk memperoleh keterampilan baru yang dapat diterapkan untuk peran yang berbeda. Selain itu, ia berpendapat bahwa keterlibatan dalam satu peran, misalnya peran orangtua, memungkinkan individu untuk memperoleh dukungan dari anggota yang relevan dalam domain tersebut, termasuk keluarga mereka, pasangan dan anakanak. Hal itu juga terjadi dalam domain kerja, dengan keterlibatan dalam peran pekerjaan memungkinkan individu untuk memperoleh dukungan dari atasan ataupun rekan kerja. Dukungan ini berguna dalam membantu individu mengintegrasikan peran ini dengan peran mereka yang lain (Greenhaus \& Parasuraman,1999). Dengan adanya adanya keyakinan diri mengelola konflik kerja-keluarga yang merupakan faktor internal yang membuat individu mampu dengan baik menghadapi dan menyelesaikan konflik yang terjadi pada domain kerja dan domain keluarga, serta ditunjang dengan adanya dukungan atasan dan dukungan keluarga yang merupakan faktor eksternal, maka gabungan dari kedua faktor tersebut akan membuat individu mengalami pengayaan kerjakeluarga yang baik.

Tabel 4.3 Uji Hipotesis Minor

\begin{tabular}{|c|l|c|c|c|}
\hline & \multicolumn{1}{|c|}{ Variabel } & r parsial & $\mathbf{P}$ & Status \\
\hline 1 & $\begin{array}{l}\text { Keyakinan Diri Mengelola } \\
\text { Konflik Kerja-Keluarga } \\
\text { dengan Pengayaan Kerja- } \\
\text { Keluarga }\end{array}$ & 0.259 & $<0.001$ & $\begin{array}{c}\mathrm{H} 2 \\
\text { diterima }\end{array}$ \\
\hline 2 & $\begin{array}{l}\text { Dukungan Atasan dengan } \\
\text { Pengayaan Kerja-Keluarga }\end{array}$ & 0.239 & $<0.001$ & $\begin{array}{c}\mathrm{H} 3 \\
\text { diterima }\end{array}$ \\
\hline 3 & $\begin{array}{l}\text { Dukungan Keluarga Besar } \\
\text { dengan Pengayaan Kerja- } \\
\text { Keluarga }\end{array}$ & 0.216 & 0.001 & $\begin{array}{c}\mathrm{H} 4 \\
\text { Diterima }\end{array}$ \\
\hline
\end{tabular}




\section{Journal of Psychological Science and Profesion (JPSP)}

Vol.1, No.1, Desember 2017

E-mail: jpsp@unpad.ac.id

Hasil uji hipotesis minor pertama diperoleh nilai $p$ kurang dari 0.05 dan nilai $r$ parsial 0.259. Hal tersebut berarti ada hubungan yang signifikan antara keyakinan diri mengelola konflik kerja-keluarga dengan pengayaan kerja-keluarga dengan mengontrol variabel dukungan atasan dan dukungan keluarga besar. Apabila dibandingkan dengan dua variabel lainnya (dukungan atasan dan dukungan keluarga besar), keyakinan diri mengelola konflik kerjakeluarga dengan pengayaan kerja-keluarga memiliki nilai $r$ parsial yang paling besar. Hal tersebut menunjukkan bahwa kekuatan hubungan keyakinan diri mengelola konflik kerjakeluarga dengan pengayaan kerja-keluarga lebih besar daripada variabel lain. Hal ini terjadi mungkin karena keyakinan diri dalam mengelola konflik kerja-keluarga merupakan faktor internal yang berasal dari dalam diri individu dan dalam kontrol individu tersebut.

Penelitian sebelumnya menunjukkan bahwa keyakinan diri individu dalam domain yang spesifik dapat memberikan informasi tentang bagaimana individu akan memahami dan mengatasi kesulitan dalam domain yang lain (Wallace,2014; Lu,2011; Lent,1994). Hasil penelitian lainnya menemukan bahwa keyakinan diri memiliki hubungan negatif dengan konflik kerja-keluarga (Hennessy, 2007). Temuan dalam penelitian Hennesy (2007) menunjukkan bahwa wanita memiliki keyakinan diri yang tinggi dalam mengelola konflik yang timbul ketika pekerjaan dan tanggung jawab keluarga mengganggu satu lain. Hasil yang diperoleh dalam penelitian ini juga sejalan dengan hasil penelitian Ruderman, Ohlott, Panzer, \& King, 2002 yang menyatakan bahwa keyakinan diri dalam satu domain dari kehidupan individu dapat berdampak pada bagaimana individu menjalani domain lain.

Hasil uji hipotesis minor kedua diperoleh nilai $p$ kurang dari 0.05 dan nilai $r$ parsial 0.239. Hal tersebut berarti ada hubungan yang signifikan antara dukungan atasan dengan pengayaan kerja-keluarga dengan mengontrol variabel keyakinan diri mengelola konflik kerja-keluarga dan dukungan keluarga besar. Berdasarkan hasil penelitian diperoleh data bahwa $17.2 \%$ partisipan mendapatkan dukungan yang tinggi dari atasan dan $70.4 \%$ mendapatkan dukungan yang sedang dari atasan. Sebagai salah satu prediktor, adanya dukungan yang cenderung tinggi tersebut memungkinkan partisipan memiliki pengayaan kerja-keluarga yang juga cenderung tinggi.
Hasil penelitian hubungan dukungan atasan dengan pengayaan kerja-keluarga tidak konsisten dalam penelitian-penelitian sebelumnya. Ada penelitian yanh menyatakan bahwa dukungan atasan berhubungan dengan pengayaan kerja-keluarga, namun ada juga penelitian yang menyatakan bahwa tidak ada hubungan yang signifikan antara dukungan atasan dengan pengayaan kerja-keluarga. Penelitian ini menemukan bahwa terdapat hubungan yang signifikan antara dukungan atasan dengan pengayaan kerja-keluarga, hasil tersebut sejalan dengan hasil penelitian Baral \& Bhargava, 2011b; McNall,Nicklin \& Masuda, 2010; Mostert \&Van Aarde, 2008. Peneliti tersebut menetapkan bahwa dukungan atasan (supervisor) secara positif terkait dengan pengayaan kerja-keluarga.

Hasil penelitian ini tidak sejalan dengan hasil penelitian Wallace (2014) yang menemukan bahwa dukungan rekan kerja dukungan adalah satu-satunya sumber dukungan dari domain kerja yang menjadi prediktor signifikan dari pengayaan kerja-keluarga untuk ayah bekerja di Afrika Selatan. Temuan tersebut hampir sama dengan Molino (2013) yang meneliti hubungan antara dukungan atasan dan dukungan rekan kerja dengan pengayaan kerja-keluarga dan menetapkan bahwa hanya dukungan rekan kerja memiliki hubungan langsung yang signifikan dengan pengayaan kerja keluarga. Kedua penelitian tersebut menemukan bahwa dukungan atasan memiliki hubungan yang signifikan dengan Opportunity Proffesional Development (OPD) yang menjadi mendiator dukungan atasan dengan pengayaan kerja-keluarga. Selanjutnya, Aryee (2005) juga menetapkan bahwa tidak ada yang signifikan hubungan antara dukungan atasan dan pengayaan kerja-keluarga dalam sampel orang tua India yang dipekerjakan secara penuh waktu.

Dukungan atasan merupakan faktor yang sangat dalam membantu karyawan mengelola baik pekerjaan mereka dan peran keluarga, dengan adanya dukungan baik berupa bantuan pekerjaa, emosional maupun informasi akan dapat menurunkan tingkat stres dalam bekerja. Akibatnya, dengan menerima dukungan atasan dari domain kerja, individu lebih mungkin untuk mengalami pengaruh sumber positif yang dapat ditransfer ke domain keluarga. Dalam sebuah organisasi dukungan atasan sangat penting untuk memberikan persetujuan pada langkah yang akan diambil oleh bawahannya, misalnya 


\section{Journal of Psychological Science and Profesion (JPSP)}

Vol.1, No.1, Desember 2017

E-mail: jpsp@unpad.ac.id

dukungan berupa ijin bagi seorang guru untuk meninggalkan tugas diklat karena anaknya sedang sakit. Dukungan dari atasan bisa berupa dukungan emosional dan praktis, serta dapat berupa dukungan informasi dalam bentuk bimbingan kerja-keluarga (Dineen, Lewicky, \& Tomlinson, 2006; Paustian-Underdahl \& Halbesleben, 2014). Bimbingan kerja-keluarga dari atasan mengacu pada petunjuk dan saran tentang cara terbaik bagi individu dalam mengelola konflik kerja-keluarga mereka, atau meningkatkan pengayaan kerja-keluarga pada saat melaksanakan tugas yang berhubungan dengan pekerjaan mereka. Akibatnya, dukungan dari atasan seseorang dapat dianggap sebagai hal penting dalam pengayaan kerja-keluarga (Paustian-Underdahl \& Halbesleben, 2014).

Hasil uji hipotesis minor yang ketiga yaitu dukungan keluarga besar dengan pengayaan kerja-keluarga, diperoleh nilai $r$ parsial 0.216 dan nilai $p$ kurang dari 0.05 yang artinya bahwa terdapat hubungan yang signifikan antara dukungan keluarga besar dengan pengayaan kerja-keluarga dengan mengontrol variabel keyakinan diri mengelola konflik kerja-keluarga dan dukungan atasan. Hasil penelitian ini sejalan dengan Aryee, 2005; Bhargava \& Baral, 2009; Karatepe \& Bekteshi, 2008 yang menemukan hubungan positif antara dukungan keluarga dan pengayaan kerja-keluarga, serta hubungan negatif antara konflik kerja-keluarga dan dukungan keluarga. Semua penelitian tersebut dilakukan dalam masyarakat kolektivis dan bahwa secara luas dukungan keluarga didefinisikan sebagai dukungan yang diterima dari anggota keluarga dan teman serta pasangan seseorang. Penelitian dari Wallace, 2014 menemukan bahwa tidak ada hubungan yang signifikan antara dukungan keluarga dengan pengayaan kerja-keluarga. Dalam penelitian tersebut satu-satunya dukungan dari domain keluarga yang signifikan dengan pengayaan kerja-keluarga adalah dukungan pasangan. Penelitian yang dilakukan Wallace (2014) mengambil sampel laki-laki pada masyarakat dengan budaya individualisme di Afrika Selatan. Dukungan keluarga besar mengacu pada dukungan yang diterima dari anggota keluarga lain selain pasangan individu atau anak-anak. Seperti seorang ibu, mertua, dan bibi dapat memberikan dukungan dengan memberikan bantuan pengasuhan anak saat individu sedang bekerja. Budaya kolektivisme di Indonesia sangat memungkinkan individu dengan mudah mendapatkan dukungan dari keluarga besar. Dukungan dari keluarga besar sangat mungkin terjadi di Indonesia dimana budaya matrilokal, patrilokal dan natalokal masih kental. Budaya matrilokal merupakan kondisi dimana setelah menikah, pasangan pengantin tinggal dan hidup bersama dengan keluarga perempuan. Adapun budaya patrilokal merupakan kondisi dimana setelah menikah, pasangan pengantin tinggal dan hidup bersama dengan keluarga laki-laki. Hal tersebut akan sangat memungkinkan pasangan individu mendapat dukungan keluarga baik dari orang tua maupun mertua. Selain itu tradisi natalokal yaitu kondisi dimana individu sesudah menikah tinggal terpisah dengan orang tua namun tetap di daerah kelahirannya juga memungkinkan adanya dukungan dari saudara dan kerabat.

Dukungan keluarga besar dianggap lebih berharga dalam masyarakat yang memiliki tingkat kolektivisme tinggi daripada di masyarakat yang individualistis. Ini adalah sejalan dengan usulan Hofstede (2011) bahwa budaya kolektivis ditandai dengan sangat kohesif dalam kelompok, di mana anggota keluarga besar memainkan peran pendukung penting sepanjang hidup individu. Sebagai imbalan atas dukungan yang teguh ini orang tersebut adalah sepenuh hati setia kepada keluarga mereka. Dukungan keluarga besar banyak ditemukan di masyrakat kolektivis yang diklasifikasikan oleh unit-unit keluarga yang lebih besar dan peningkatan interaksi dengan diperpanjang anggota keluarga. Dengan adanya dukungan dari keluarga besar terutama dalam tugas rumah tangga dan pengasuhan anak akan mendorong terjadinya pengayaan kerja-keluarga. Individu dapat bekerja dengan tenang dan fokus karena sudah ada yang mengasuh anaknya di rumah sehingga performa kerja juga maksimal, dengan demikian ada pengaruh positif yang ditransfer dari domain keluarga ke domain kerja

\section{SIMPULAN}

Berdasarkan hasil penelitian ini dapat disimpulkan bahwa ada hubungan yang signifikan antara keyakinan diri mengelola konflik kerja-keluarga, dukungan atasan, dan dukungan keluarga besar dengan pengayaan kerjakeluarga pada guru. Keyakinan diri mengelola konflik kerja-keluarga memiliki hubungan paling 


\section{Journal of Psychological Science and Profesion (JPSP)}

Vol.1, No.1, Desember 2017

E-mail: jpsp@unpad.ac.id

kuat dengan pengayaan kerja-keluarga,diikuti oleh dukungan atasan dan keluarga besar.

Saran yang peneliti berikan bagi sekolah yaitu agar sekolah mengadakan training tentang bagaimana cara mengelola konflik kerja-keluarga pada guru serta mengadakan program pembinaan kerja ramah keluarga. Penelitian ini dapat dikembangkan lebih lanjut dengan membandingkan pengayaan kerja-keluarga dengan latar budaya yang berbeda pada penelitian selanjutnya. Penelitian selanjutnya juga disarankan untuk menggali sumber dukungan lainnya seperti dukungan dari asisten rumah tangga, karena dalam penelitian ini ditemukan pula bahwa banyak pasangan yang mendapatkan dukungan dari asisten rumah tangga dalam melaksanakan tugas rumah tangga mereka sehari-hari.

\section{DAFTAR PUSTAKA}

Andhini, L.P.R., (2016). Hubungan antara dukungan pasangan, dukungan atasan, dan work-family conflict self-efficacy, dengan pengayaan kerja-keluarga. Thesis Magister Psikologi Sains. Tidak diterbitkan. Universitas Surabaya, Surabaya.

Antani, A. \& Ayman, R. (April, 2003). Gender, Social Support and the Experience of WorkFamily Conflict. Paper presented at European Academy of Management, Milan, Italy.

Artiawati. (2004). Work family Conflict in Asian Cultural Context: The Case of Indonesia, makalah dipresentasikan sebagai bagian dari simposium Project 3535 pada International Conference Society for Industrial and Organizational Psychology, Chicago, USA.

Artiawati. (2012). Konflik kerja-keluarga pada jurnalis di Jawa dan Bali (model konflik kerja-keluarga dengan ideologi peran gender, beban peran berlebih, dukungan sosial, dan kepribadian sebagai anteseden; rasa bersalah dan kesejahteraan psikologis sebagai konsekuensi). Disertasi tidak diterbitkan. Program Pascasarjana, Universitas Padjadjaran, Bandung.

Artiawati (2017). The Work-Family Interface in Indonesia, chapter 10 in Korabik, K., Aycan, Z \& Ayman, R.(Ed.). The Work-
Family Interface in Global Context, Routledge: New York

Aryee, S., Srinivas, E. S., \& Tan, H. H. (2005). Rhythms of life: Antecedents and outcomes of workfamily balance in employed parents. Journal of Applied Psychology, 90(1), 132146.

Baral, R., \& Bhargava, S.(2009). Antecedents and consequences of work-family enrichment among Indian managers. Psychological Studies, 54(3):213-225.

Baral, R., \& Bhargava, S. (2011b). Predictors of work-family enrichment: Moderating effect of core self-evaluations. Journal of Indian Business Research, 3(4), 220-243.

Carlson, D.R., Kacmar, K.M., Wayne, J.H., \& Grzywacz, J.G. (2006). Measuring the positive side of the work-family interface: Development and validation of a work family enrichment scale. Journal of Vocational Behavior, 68, 131-164.

Cinamon, G. R. (2003). Work-family conflict selfefficacy and career plans of young adults. In press.

Dineen, B.R., Lewicki, R.J., Tomlinson,E.C. (2006). Supervisory guidance and behavioral integrity: relationships with employee citizenship and deviant behavior. Journal of Applied Psychology, 91(3):62235.

Ewing, Robyn Ann and Smith, David Langley. (2003). Retaining quality beginning teachers in the profession. English Teaching: Practice and Critique May, 2003, Volume 2, Number 1 pp 15-32.

Gareis, Karen C.,Barnett,Rosalind C., Ertel, karen A., Berkman, Lisa F (2009). WorkFamily Enrichment and Conflict: Additive Effects, Buffering, or Balance?. Journal of Marriage and Family 71:696-707.

Greenhaus, J. H., \& Parasuraman, S. (1999). Research on work, family, and gender: Current status and future direction. In G. N. Powel (Ed.), Handbook of gender and work (pp. 391-412). Newbury Park, CA:Sage.

Greenhaus, J.H. \& Powell, G.N. (2006). When work and family are allies: $A$ theory of workfamily enrichment. Academy of Management Review, 31 (1), 72-92.

Greenhaus, J., and Singh, Romila. (2007). Mentoring and the Work-Family Interface. Handbook of Mentoring at Work, 


\section{Journal of Psychological Science and Profesion (JPSP)}

Vol.1, No.1, Desember 2017

E-mail: jpsp@unpad.ac.id

Ed. Belle Ragins and Kathy Kram. Thousand Oaks, CA: Sage.

Hennessy, K. D. (2007). Work-family balance: an exploration of conflict and enrichment for women in a traditional occupation. Dissertation submitted to the Faculty of the Graduate School of the University of Maryland.

Hofstede. G. (2011). Dimensionalizing cultures: The Hofstede model in context. Online Readings in Psychology and Culture, 2(1). doi: 10.9707/2307-0919.1014

ILO. (2015). Tren ketenagakerjaan dan sosial di Indonesia 2014 - 2015: Memperkuat daya saing dan produktivitas melalui pekerjaan layak/Kantor. Perburuhan Internasional. Jakarta: ILO.

Karatepe, Osman M., Bekteshi, Lorina.(2008). Antecedents and outcomes of work-family facilitation and family-work facilitation among frontline hotel employees. International Journal of Hospitality Management 27(4):517-528.

Kossek, E., Pichler, S., Bodner, T. \& Hammer, L. 2011. Workplace social support and workfamily conflict: A meta-analysis clarifying the influence of general and work-family specific supervisor and organizational support. Journal of Personnel Psychology, 64: 289-313.

Lent, R.W., Brown, S.D., \& Hackett, G. (1994). Toward a unifying social cognitive Theory of career and academic interest, choice, and performance. Journal of Vocational Behavior, 45, 79-122.

Lu, Luo. (2011). A Chinese longitudinal study on work/family enrichment. Department of Business Administration, National Taiwan University, Taipei City, Taiwan, Republic of China. Journal of Career Development International Vol. 16 No. 4, 2011 pp. 385400

McNall, L. A., Nicklin, J. M., \& Masuda, A. D. (2010). A meta-analytic review of the consequences associated with work-family enrichment. Journal of Business and Psychology, 25(3), 381- 396.

Molino, M., Ghislieri, C., \& Cortese, C. G. (2013). When work enriches family-life: the mediational role of professional development opportunities. Journal of Workplace Learning, 25(2), 98-113.

Mostert, Karina \& Van Aarde, Adele. (2008). Work-home interaction of Working females: What is the role of job and home characteristics?.SA Journal of Industrial Psychology 34(3).

Paustian-Underdahl, S. \& Halbesleben, J. (2014). Examining the Influence of Climate, Supervisor Guidance, and Behavioral Integrity on Work-Family Conflict: A Demands and Resources Approach. Journal of Organizational Behavior, 35(4), 447-463.

Powell, G. N., \& Greenhaus, J. H. (2006). Is the opposite of positive negative? Untangling the complex relationship between workfamily enrichment and conflict. Career Development International, 11(7), 650-659.

Rao, Kiran., Apte, Mridula \& Subbakrishna,D.K. (2003). Coping and Subjective Wellbeing in Women with Multiple Roles. International Journal of Social Psychiatry 49(3):175-84

Ruderman, M. N.; Ohlott, P. J.; Panzer, K.; \& King, S. N. (2002). Benefits of multiple roles for managerial women. Academy of Management Journal, 45(2), 369-386.

Shein,Jennifer and Chen,P Charles. (2011). Work Family Enrichment : A Research of Positive Transfer. Sense of Publisher : University of Toronto, Canada

Wallace, Chelsea Lee. (2014). The SupportBased Factors That Facilitate Work-Family Enrichment for Working Fathers in South Africa. A dissertation submitted in partial fulfilment of the requirements for the award of the Degree of Master of Social Science in Organisational Psychology, University of Cape Town. 


\section{- Journal of Psychological Science and Profession" \\ Jurnoil Palkoleol Soins don Frotesi}

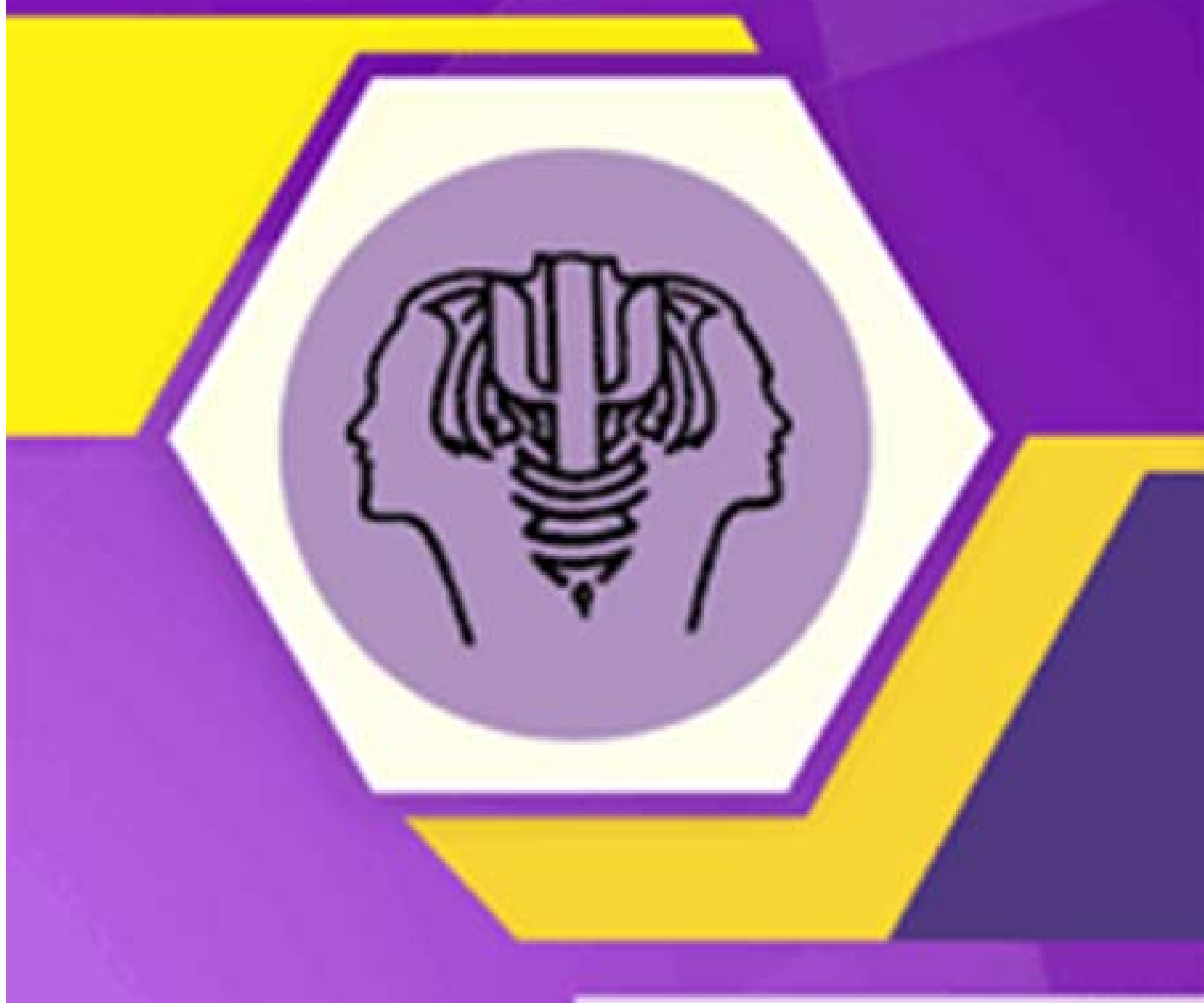

Fokultos Psikologi

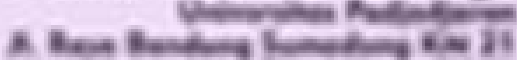

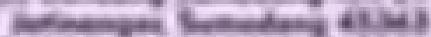

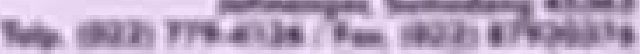

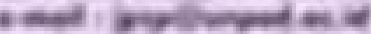

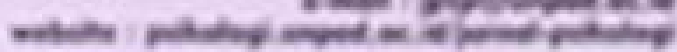




\section{Ketua Editor}

Yulians Hansmi, Fakultes Psikologi, Universitos Padjodjaran, Indanesis

Dewan editorial

Fredrick Dermswan Purbs, Scopus ID:57191756452 Fakultss Psikologi Universitos Podjedjaran, Indonesis

Anissa Lestari Kodiyana, Scopus ID: 57193234513 Fakultss Psikologi - Universitss Podjodjaran, Indanesis, Indanesis

Editor Bagian

Aulis Hansfitri

Kardins Dolimunthe, Fakuttss Psikologi, Universitss Podjodjaran, Indanesis

Fide Nirmals Nugrahs, Scopus ID: 57193234508 Tekam University, Bandung Wert leve

Hamdi Muluk, Scopus ID: 34977218900 Foculty of Psychology, Universites Indonesis, Indonesis

Sri Tistri, Scopus ID: 55639319900 Tarumansgars University, Indanexis

Urip Purwana, Scopus ID: 6506117537 Fakultss Psikologi-Universitss Podjodjaran, Indanesis

Jumal ini terideks di:

\section{Googte 1 Crossref CA GARUDA \BasE Dimensions @isinta}

0000221742 
Jurnal Psikologi Sains dan Profesi (Journal of Psychological Science and Profession)

DOI: nttps://dai.arg/10.24198/jpsp.v13

Daftar Isi

Artikel

HUBUNGAN KEYAKINAN DIRI MENGELOLA KONFLIK KERJA-KELUARGA, DUKUNGAN ATASAN, DAN

d $10.24198 / \mathrm{jpsp} . v 13.14968$

3. Nesi Plg Astutik, - Artiavati

EFEKTIVITAS COGNITIVE BEHAVIOR ART THERAPY UNTUK MENINGKATKAN SELF-ESTEEM REMAIA OBESITAS YANG MENUADI KORBAN BULLYING

d $10.24198 / \mathrm{jpsp} . v 13.14969$

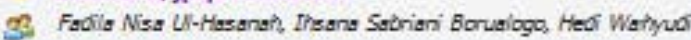

PERBEDAAN SIKAP IBU HAMIL TERHADAP DOKTER KANDUNGAN PRIA DAN WANITA

d. $10.24198 /$ jpsp.v113.15231

34 Nogo Tejens, Nindye Putri Aprodits, Keumale Nuranti, Aulis Iskandersyar?

PENGARUH NILAI BUDAYA SUNDA DALAM UPAYA PENINGKATAN KESEJAHTERAAN PSIKOLOGIS KORBAN

$26-35$ BENCANA TANAH LONGSOR

d. $10.24198 / \mathrm{jpsp} . \mathrm{v} 133.15232$

93. Ansesa Lestari Kadyono, Dians Harding

PERAN KUALTTAS KEHIDUPAN KERIA DAN PERSEPSI PELUANG KERJA TERHADAP INTENSI PINDAH KERJA

d. $10.24198 / \mathrm{jpsp} . \mathrm{v} 1 \mathrm{i3} .15228$

33 Yuohistirs Victoris, Zamracite Zamralita, Kiky Saraswat

ADAPTASI ALAT UKUR PERSPECTIVE TAKING PADA REMAJA

d. $10.24198 / \mathrm{jpsp} . v 133.15229$

98 N Futu Ays, Hendhisti Agustioni, Langgessari Esari Novianti

PEMAKNAAN LOYALITAS KARYAWAN PADA GENERASI XDAN GENERASI Y (Studi Pada Karyawan Di Indonesia)

$10.24198 / \mathrm{jpsp} . v 13.15230$

ge Ayu Dri Nindyeti

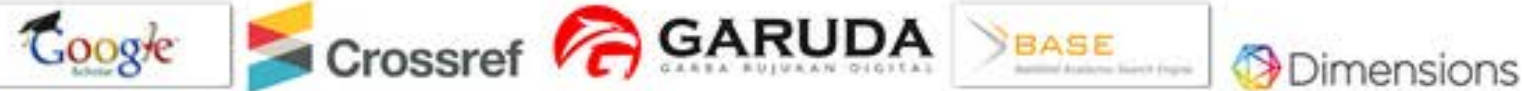
Cînta 